Spanish women's attitudes towards post-fertilization effects of birth control methods

\author{
Cristina Lopez-del Burgo ${ }^{\text {a }}$ \\ Carmen Marina Lopez-de Fez ${ }^{\text {a }}$ \\ Alfonso Osorio ${ }^{\mathrm{b}}$ \\ José Lopez Guzmán ${ }^{c}$ \\ Jokin de Irala $^{\text {a }}$
}

${ }^{\text {a }}$ Department of Preventive Medicine and Public Health. School of Medicine, University of Navarra, Irunlarrea 1, 31008 Pamplona, Spain

${ }^{b}$ Department of Education. University of Navarra. Pamplona, Spain

${ }^{\mathrm{c}}$ Department of Biomedical Humanities. School of Medicine. University of Navarra. Pamplona, Spain.

*Corresponding author:

Tel: +34948425600 (ext. 6360) Fax: +34948425649

E-mail address: cldelburgo@unav.es

\begin{abstract}
Published in:
European Journal of Obstetrics \& Gynecology and Reproductive Biology (http://www.ejog.org/)
\end{abstract}

See original article in the Journal's web page:

http://www.sciencedirect.com/science/article/pii/S0301211510001466

\title{
Cite as:
}

C. Lopez-del Burgo, C.M. Lopez-de Fez, A. Osorio, J.L. Guzman and J. de Irala, Spanish women's attitudes towards post-fertilization effects of birth control methods. Eur J Obstet Gynecol Reprod Biol, 151 (2010), pp. 56-61. 


\section{Abstract}

Objective: Some methods of family planning may occasionally work after fertilization or implantation. These effects may be important to some women. We explored Spanish women's attitudes towards these potential mechanisms of action of family planning methods.

Study design: Cross-sectional study in a Spanish representative sample of 848 potentially fertile women, aged 18-49. Data were collected using a 30-item questionnaire about family planning. Logistic regression was used to identify variables associated with women's attitudes towards postfertilization effects.

Results: The majority of women were married, held an academic degree and had at least one child. Forty-five percent of women would not consider using a method that may work after fertilization and 57\% would not consider using one that may work after implantation. Fortyeight percent of the sample would stop using a method if they learned that it sometimes works after fertilization, increasing to $63 \%$ when referring to a method that sometimes works after implantation. Women who believe that human life begins at fertilization, those who believe it is important to distinguish between spontaneous and induced embryo losses and women who report having a religion were less likely to consider the use of a method with some postfertilization effects.

Conclusion: The possibility of postfertilization effects may influence Spanish women's choice of a FP method. Information about mechanisms of action of birth control methods should be disclosed to women so that they can make informed choices.

Key words: Mechanism of action, informed consent, oral contraceptives, emergency contraception, intrauterine device. 


\section{Introduction}

According to the United States Agency for International Development, family planning (FP) programs are based on two fundamental principles: voluntarism and informed choice [1]. People are encouraged to choose the method that meets their own needs and desires, after accessing and understanding all the information. Informed choices in FP are associated with satisfaction and compliance with the method, and consequently with less failures [2-4].

The World Health Organization recommends that health providers inform women about every aspect of each FP method: effectiveness, correct use, side-effects, mechanism of action, health risks and benefits, reversibility and protection against sexually transmitted infections [5]. Clinical discussion usually focuses on benefits and risks, possible adverse effects and instructions for correct use [6,7]. Mechanism of action may receive less attention in this setting.

Scientific evidence suggests that some methods, including oral contraceptives, emergency contraception (EC), intrauterine devices and even lactational-amenorrhea method, can exhibit several effects in addition to preventing ovulation, such as biochemical or structural changes in the endometrium or alterations of fallopian tube [8-15]. These effects may sometimes prevent implantation (a postfertilization effect) and could be in conflict with some women's beliefs or value systems [16-19]. A study conducted in several clinics in Utah and Oklahoma, (USA) showed that $53 \%$ and $74 \%$ of women responded "no" when asked if they would use a method that acts after fertilization or after implantation, respectively [20]. New contraceptive methods are being developed (such as new forms of EC) that may work after implantation [21], and early abortion (medical or surgical) is sometimes considered as a method to prevent unwanted births [22]. Women may have similar concerns about methods that can have postimplantation effects. Therefore, more thorough discussions of the mechanisms of action 
of methods could improve informed consent, especially if women have personal objections to postfertilization effects.

We hypothesized that Spanish women's choice in FP could be influenced by their perceptions about mechanisms of action. Consequently, we decided to explore Spanish women's opinions and attitudes about the mechanism of action of FP methods. Specifically, we wanted to assess whether women would consider using a method that may exhibit a postfertilization or a postimplantation effect and whether they would consider continuing their use after learning about their potential posfertilization or postimplantation effects.

\section{Material and Methods}

\section{The sample}

The study was carried out as a cross-sectional survey in a nationally representative sample of 848 potentially fertile Spanish women. Women under 18 or above 49 and those who had any surgery or pre-existing conditions causing them to be infertile/sterile were excluded.

Our survey was part of an Omnibus or "multi-topic" survey. Random, stratified, and multistage sampling was used to select women. Variables used to stratify the sample and match national data from Spain's National Statistical Institute included sex, age, geographic location and population size of residence. This study depends on the use of multivariate analysis to evaluate associations and adjust for confounders. A sample size of about 850 subjects was initially targeted to meet these needs. We worked with the criteria that 10 subjects would be needed per parameter included in a statistical model adjusting for confounding [23, 24]. By parameter we mean each continuous variable and/or each dummy variable from categorical variables in a model.

\section{Questionnaire}

An anonymous, 30-item questionnaire about knowledge, beliefs and attitudes related to possible mechanisms of action of FP methods was administered to participants. Sometimes 
abortion is offered to prevent unwanted births [22], so they were also listed among the methods. The questionnaire was originally developed in English and translated into Spanish. The English version was previously validated by assessing consistency of responses [20]. The Spanish version was tested in a cross-sectional study carried out in Pamplona (Spain) and details of this study have been published elsewhere [25]. The questionnaire includes a picture, an explanation of the female reproductive system and the stages of human reproduction. The period before fertilization is called "stage 1", the period between fertilization and implantation "stage 2" and the period after implantation of the early embryo in the uterus "stage 3". No additional verbal information was given to the participants. Demographic and personal information was asked at the conclusion of the questionnaire. The questionnaire is available from the authors upon request. It was approved by the Ethics Committee at the University of Navarra.

\section{Data collection}

Data were collected between March and September of 2005 by research assistants from the GFK-Emer Market Research Company, using the Computer-Assisted Personal Interviewing method. Women entered their responses on the computer screen. Before collecting data, research assistants gave participants a letter explaining that filling out the questionnaire constituted voluntary participation. No incentives were given.

\section{Analysis}

Data were analysed using SPSS version 13.0. We calculated proportions and their confidence intervals based on the normal approximation. We used non-conditional logistic regression to assess the characteristics independently associated with four outcome variables: (1) would use a method that occasionally works after fertilization, (2) would use a method that occasionally works after implantation, (3) would continue using a method after learning it works after fertilization and (4) would continue using a method after learning it works after implantation. 
We checked for inconsistent responses to identify subjects that were possibly not giving valid responses and performed subsequent sensitivity analyses. The questions about the intention to use a method that may act after fertilization/implantation, the beliefs about how methods may act and the reported use of a specific method were used to identify inconsistencies. For example, we classified as inconsistent the answers of women who stated they would not use methods acting between fertilization and implantation but that stated they would use methods acting after implantation.

\section{Results}

\section{Description of the sample}

Eight-hundred forty-eight women participated in the study (Table 1). Women were mostly aged 25-34 years. The majority had completed high school (54\%) and were married (56.7\%). Most women (79\%) were Catholic. Nearly half had no children and the majority (65\%) would like to get pregnant in the future. Forty percent of women believed that human life begins at fertilization. The most common methods of FP currently used by participants were condoms (38\%) and oral contraceptives (30\%) (Table 2).

We identified 44 (5\%) inconsistent questionnaires, where responses about beliefs and/or intentions contradicted actual use or where two intentions were directly contradictory. All analyses were repeated excluding these inconsistencies, obtaining substantially the same results. We present the results of all the surveyed women to maximize representativeness.

\section{Opinions and attitudes related to postfertilization effects}

Forty-five percent of the women reported that they would not consider using a method that sometimes works after fertilization and $57 \%$ would not consider using one that sometimes works after implantation. Moreover, $48 \%$ of the women said they would stop using a method if they learned that it works after fertilization and $63 \%$ if it works after implantation. Most 
women $(63 \%)$ responded that it is important to distinguish between spontaneous embryo losses and those caused by FP methods (Table 3).

Among women using a method at the moment of the survey, $48.2 \%$ reported that the doctor or provider had explained how the method worked, while $39 \%$ said he/she had not. An additional $13 \%$ were using a method not obtained from a doctor.

Several variables were independently associated with a woman's reported decision to use a method that sometimes could work after fertilization. Women who believe human life begins at implantation or some point after it were more likely to report they would use or continue using such methods. Conversely, married women, those who report having a religion and those who believe that it is important to distinguish natural from non-natural embryo losses affirmed they would be less likely to use or continue using a method after being informed about its postfertilization effects (Table 4).

Regarding methods that sometimes work after implantation, women who believe that human life begins at some point after implantation stated they would be more likely to use and also continue using them after learning about their mechanism of action. In contrast, women who considered that it is relevant to distinguish natural embryo loss from non-natural loss reported they would be less likely to continue using a FP method that can work after implantation, if they learned that it worked in this way (Table 4).

The belief about the beginning of human life was the sole variable independently associated with all four outcome variables.

\section{Discussion}

Our results show that mechanisms of action may influence Spanish women's choice of a FP method. A study among 18-50 year-old female patients from two family medicine clinics in the south-eastern United States found that 20\% reported that they would use EC only if it worked before fertilization and $18 \%$ would use it only if it works before implantation [26]. 
Our previous study in a city of Spain showed that $40 \%$ of women would not consider using a method with postfertilization effects [25].

The belief about when human life begins is associated with women's potential decisions about postfertilization or postimplantation effects of FP methods. This is consistent with studies on women's decisions about EC use. Romo et al., in a study carried out in Texas (USA), found that women who believed that EC prevents implantation were less willing to use it [27]. Gould et al. explored knowledge and attitudes about EC and medical abortion among subjects of reproductive age in Mexico. They found that those who believe that life begins at fertilization considered EC to be an abortive method rather than a contraceptive one, because of its anti-implantation effect [28].

Religious beliefs may play a role in decision-making about contraception [29-31]. Our results show that women who have a religion are less likely to use or to continue using a method with postfertilization effects. In contrast, we did not find this association for methods with postimplantation effects. Perhaps there is a greater consensus in society regarding the consideration that should be given to the human embryo after implantation as compared to after fertilization [32], where religion plays a greater role defining opinions. Only $22 \%$ of the women in this study considered their faith an important influence in their lives and only $8 \%$ attend church regularly. Even though religion does not always influence people, there does appear to be residual discomfort with some methods of FP.

Decisions about not using a FP method with postfertilization effects were also associated with whether women consider differences in the causes of embryo loss to be important. At the Second international conference on intra-uterine contraception, sponsored by The Population Council in 1964, Dr. Wishik noted that acceptance or rejection of birth control would depend on whether it caused an early abortion [33]. Indeed, our data confirm that the belief of when life begins can determine FP choices. 
In our study, $39 \%$ of the women reported that their doctor or provider had not explained how the method they were using worked. Since some women's belief systems are so intrinsically tied to their FP methods, it is imperative that sufficient understanding of mechanism of action occurs at the provider level to assure a fully informed choice [2].

The present study has limitations. There may be some differences between intentions of use and actual choices of FP methods and behaviour. Our study does not assess the importance of potential postfertilization effects in comparison with other characteristics such as effectiveness or side effects. Results of this Spanish representative sample may not be applicable to other cultural settings.

Some women may have possibly had some difficulty in understanding the stages of human reproduction, although only 5\% returned inconsistent responses, and the results were essentially the same when such responses were excluded. Our results are consistent with the findings of our prior study carried out in a city of Spain among women with a similar education level [25]. There is further evidence that women understood the mechanisms of action of specific FP methods: some methods, including the condom, tubal ligation or abortion, have a very well-recognized single mechanism of action. The majority of women responded correctly when identifying these methods with a well-established single mechanism. For example, $86.4 \%, 67.5 \%$ and $72 \%$ of women responded that condoms, sterilization and abstinence act only at stage 1 (before fertilization), respectively. These figures are similar to those found in previous studies where the same questionnaire was used $[20,34]$

As part of the questionnaire, we asked "Is it an important difference for you if the loss of an embryo is natural or caused by a method of birth control?" This could be interpreted in different ways. The term "natural" could be understood positively and "caused by" might be interpreted negatively. However, women who responded that this difference was important 
also reported that it did not matter whether a method causes an embryo loss frequently or rarely. This suggests that different wording of this question would be unlikely to substantially change the responses for these women. Although there are authors that have addressed the ethical difference regarding the cause of early embryo losses [15], to the best of our knowledge this is the first study that addresses this issue among women.

This is the first study addressing the topic of mechanisms of action of FP carried out in a representative sample of a country. We did not describe, during the survey, what is known or not known about the mechanism of action of any FP methods and we did not give any instructions about when human life begins, because we did not want to influence women's answers. In addition, the questionnaire was completely self-administered, avoiding any interviewer bias. Although some women consider a method as "abortive" or "abortifacient" if it has an anti-implantation effect $[18,28,35]$, we preferred to use the term "postfertilization" when referring to this mechanism of action. Moreover, although postimplantation effects are considered as abortion in scientific forums [26, 36-38], we also avoided the term "abortifacient" to use less value-laden wordings throughout our study.

\section{Conclusion}

Our study finds that potential postfertilization effects of FP methods may influence Spanish women's choice. Attitudes and opinions about postfertilization effects were strongly associated with personal beliefs about when human life begins. Most women held the opinion that it is important to distinguish between spontaneous embryo losses and those caused by FP methods. We encourage health professionals to provide accurate information about potential postfertilization effects of FP methods in order to improve informed choices in the selection of FP methods. 


\section{Acknowledgements}

This study was funded by the Institute of Family Sciences, University of Navarra. We thank the women who participated in our study. We also thank Mathew Hanley for editing and proof reading the English, Dr. Joseph B Stanford (University of Utah) and Dr. Rafael T Mikolajczyk (University of Bielefeld) who first studied this issue in the USA. Dr. Stanford commented on our analysis and manuscript.

\section{Disclosure of interests}

The authors declare that they have no competing interests. 


\section{References}

1. United States Agency for International Development (USAID). USAID's Family Planning Guiding Principles and U.S. Legislative and Policy Requirements. Available in: http://wwwusaidgov/our_work/global health/pop/voluntarismhtml.

2. Upadhyay UD. Informed choice in family planning. Helping people decide. Popul Rep J 2001:1-39.

3. Bajos N, Leridon H, Goulard H, Oustry P, Job-Spira N. Contraception: from accessibility to efficiency. Hum Reprod 2003;18:994-9.

4. Frost JJ, Singh S, Finer LB. Factors associated with contraceptive use and nonuse, United States, 2004. Perspect Sex Reprod Health 2007;39:90-9.

5. World Health Organization, ed. Improving access to quality care in family planning: Medical eligibility criteria for contraceptive use. Geneva; 2004 (Available in: www. who.int/reproductive-health/publications/MEC_3/mec.pdf).

6. Kottke M, Cwiak C. Nondaily contraceptive options user benefits, potential for high continuation, and counseling issues. Obstet Gynecol Surv 2008;63:661-8.

7. Spencer AL, Bonnema R, McNamara MC. Helping Women Choose Appropriate Hormonal Contraception: Update on Risks, Benefits, and Indications. Am J Med 2009;122:497-506.

8. Frye CA. An overview of oral contraceptives: mechanism of action and clinical use. Neurology 2006;66:S29-36.

9. Pierson RA, Archer DF, Moreau M, Shangold GA, Fisher AC, Creasy GW. Ortho Evra/Evra versus oral contraceptives: follicular development and ovulation in normal cycles and after an intentional dosing error. Fertil Steril 2003;80:34-42.

10. Mikolajczyk RT, Stanford JB. Levonorgestrel emergency contraception: a joint analysis of effectiveness and mechanism of action. Fertil Steril 2007;88:565-71.

11. Trussell J, Jordan B. Mechanism of action of emergency contraceptive pills. Contraception 2006;74:87-9.

12. Stanford JB, Mikolajczyk RT. Mechanisms of action of intrauterine devices: update and estimation of postfertilization effects. Am J Obstet Gynecol 2002;187:1699-708.

13. French R, Van Vliet H, Cowan F, et al. Hormonally impregnated intrauterine systems (IUSs) versus other forms of reversible contraceptives as effective methods of preventing pregnancy. Cochrane Database Syst Rev 2004:CD001776.

14. Spona J, Binder N, Höschen K, Feichtinger W. Contraceptive efficacy and safety of a low-dose oral contraceptive, $(0.03 \mathrm{mg}$ ethinyl oestradiol and $2 \mathrm{mg}$ chlormadinone acetate) Belara ${ }^{\circledR}$, over three medication cycles. Eur J Contracept Reprod Health Care 2008;13:39 - 48.

15. Mikolajczyk RT, Stanford JB. The empirical and ethical questions of induced versus natural losses of preimplantation embryos. Contraception 2007;76:256.

16. Larimore WL, Stanford JB. Postfertilization effects of oral contraceptives and their relationship to informed consent. Arch Fam Med 2000;9:126-33.

17. Spinnato JA, 2nd. Mechanism of action of intrauterine contraceptive devices and its relation to informed consent. Am J Obstet Gynecol 1997;176:503-6.

18. Larimore WL, Stanford JB, Kahlenborn C. Does pregnancy begin at fertilization? Fam Med 2004;36:690-1; author reply 1.

19. Stanford JB. Emergency contraception: overestimated effectiveness and questionable expectations. Clin Pharmacol Ther 2008;83:19-21. 
20. Dye HM, Stanford JB, Alder SC, Kim HS, Murphy PA. Women and postfertilization effects of birth control: consistency of beliefs, intentions and reported use. BMC Womens Health 2005;5:11.

21. Sarkar NN. The potential of mifepristone (RU-486) as an emergency contraceptive drug. Acta Obstet Gynecol Scand 2005;84:309-16.

22. Gasman N, Blandon MM, Crane BB. Abortion, social inequity, and women's health: Obstetrician-gynecologists as agents of change. Int J Gynecol Obstet 2006;94:310-6.

23. Hosmer D, Lemeshow S. Applied Logistic Regression. 2nd ed. N York: Willey; 2000.

24. Vittinghoff E, McCulloch CE. Relaxing the rule of ten events per variable in logistic and Cox regression. Am J Epidemiol 2007;165:710-8.

25. De Irala J, Lopez del Burgo C, de Fez CM, Arredondo J, Mikolajczyk RT, Stanford JB. Women's attitudes towards mechanisms of action of family planning methods: survey in primary health centres in Pamplona, Spain. BMC Womens Health 2007;7:10.

26. Campbell JW, III, Busby SC, Steyer TE. Attitudes and Beliefs About Emergency Contraception Among Patients at Academic Family Medicine Clinics. Ann Fam Med 2008;6:S23-7.

27. Romo LF, Berenson $\mathrm{AB}, \mathrm{Wu} \mathrm{ZH}$. The role of misconceptions on Latino women's acceptance of emergency contraceptive pills. Contraception 2004;69:227-35.

28. Gould H, Ellertson C, Corona G. Knowledge and attitudes about the differences between emergency contraception and medical abortion among middle-class women and men of reproductive age in Mexico City. Contraception 2002;66:417-26.

29. Srikanthan A, Reid RL. Religious and cultural influences on contraception. J Obstet Gynaecol Can 2008;30:129-37.

30. Romo LF, Berenson AB, Segars A. Sociocultural and religious influences on the normative contraceptive practices of Latino women in the United States. Contraception 2004;69:219-25.

31. Qureshi B. Transcultural aspects of family planning and reproductive healthcare. J Fam Plann Reprod Health Care 2001;27:3-5.

32. American College of Obstetricians and Gynecologists (ACOG). ACOG Committee Opinion No. 347: Using Preimplantation Embryos for Research. Obstetrics \& Gynecology 2006;108:1305-17.

33. Segal SJ, Southan AL, Shafer KD. Intra-uterine Contraception. Proceedings of the Second International Conference. 1964 New York City. Excerpta Medica International Congress Series 1965;86.

34. Lopez del Burgo C, Lopez de Fez C, Herranz Barbero A, Saiz Mendiguren R, de Irala J. Knowledge of the mechanisms of action of birth control methods. Prog Obstet Ginecol 2006;49:424-33.

35. Stanford JB, Larimore WL. Description of emergency contraception in the media. Contraception 2005;72:394-5; author reply 6-7.

36. Wallace JL, Wu J, Weinstein J, Gorenflo DW, Fetters MD. Emergency contraception: knowledge and attitudes of family medicine providers. Fam Med 2004;36:417-22.

37. Uzuner A, Unalan P, Akman M, et al. Providers' knowledge of, attitude to and practice of emergency contraception. Eur J Contracept Reprod Health Care 2005;10:43-50.

38. Spinnato JA. Informed consent and the redefining of conception: a decision illconceived? J Matern Fetal Med 1998;7:264-8. 


\section{Tables}

Table 1. Characteristics of the participants

\begin{tabular}{|c|c|c|c|}
\hline CHARACTERISTICS & $\mathbf{n}$ & $(\%)$ & $95 \%$ CI \\
\hline $\begin{array}{l}\text { Age groups } \\
\begin{array}{l}18-24 \\
25-34 \\
35-44 \\
45-49 \\
\text { Total }\end{array}\end{array}$ & $\begin{array}{r}200 \\
331 \\
244 \\
73 \\
848\end{array}$ & $\begin{array}{l}(23.6) \\
(39) \\
(28.8) \\
(8.6) \\
(100)\end{array}$ & $\begin{array}{l}(20.8-26.6) \\
(35.7-42.4) \\
(25.7-31.9) \\
(6.8-10.7)\end{array}$ \\
\hline $\begin{array}{l}\text { Country of origin } \\
\text { Spain } \\
\text { Central/South-America } \\
\text { East Europe } \\
\text { Africa } \\
\text { USA } \\
\text { Other countries } \\
\text { Total }\end{array}$ & $\begin{array}{r}770 \\
54 \\
5 \\
5 \\
4 \\
8 \\
846\end{array}$ & $\begin{array}{l}(91.0) \\
(6.4) \\
(0.6) \\
(0.6) \\
(0.5) \\
(0.9) \\
(100)\end{array}$ & $\begin{array}{l}(88.9-92.9) \\
(4.8-8.2) \\
(0.2-1.4) \\
(0.2-1.4) \\
(0.1-1.2) \\
(0.4-1.8)\end{array}$ \\
\hline $\begin{array}{l}\text { Education } \\
\text { Primary/compulsory school } \\
\text { High school/Technical collage* } \\
\text { University degree (3 years) } \\
\text { University graduate, doctorate } \\
\text { degree (Ph.D.) } \\
\text { Total }\end{array}$ & $\begin{array}{r}389 \\
278 \\
99 \\
81 \\
847\end{array}$ & $\begin{array}{l}(46) \\
(32.8) \\
(11.7) \\
(9.5) \\
(100)\end{array}$ & $\begin{array}{l}(42.5-49.3) \\
(29.6-36.1) \\
(9.6-14.0) \\
(7.6-11.7)\end{array}$ \\
\hline $\begin{array}{l}\text { Annual income } \\
<20.000 € / \text { year } \\
20-50.000 € / \text { year } \\
>50.000 € / \text { year } \\
\text { Do not know } \\
\text { Total }\end{array}$ & $\begin{array}{r}243 \\
174 \\
12 \\
417 \\
846\end{array}$ & $\begin{array}{l}(28.7) \\
(20.5) \\
(1.4) \\
(49.3) \\
(100)\end{array}$ & $\begin{array}{l}(25.7-31.9) \\
(17.9-23.4) \\
(0.7-2.5) \\
(45.9-52.7)\end{array}$ \\
\hline $\begin{array}{l}\text { Marital status } \\
\text { Married } \\
\text { Single } \\
\text { Widow } \\
\text { Separated/ divorced } \\
\text { Total }\end{array}$ & $\begin{array}{r}486 \\
307 \\
15 \\
37 \\
845\end{array}$ & $\begin{array}{l}(57.5) \\
(36.3) \\
(1.8) \\
(4.4) \\
(100)\end{array}$ & $\begin{array}{l}(54.1-60.9) \\
(33.1-39.7) \\
(1.0-2.9) \\
(3.1-5.9)\end{array}$ \\
\hline $\begin{array}{l}\text { Religion } \\
\text { None } \\
\text { Catholic } \\
\text { Other } \\
\text { Total }\end{array}$ & $\begin{array}{r}164 \\
669 \\
15 \\
848\end{array}$ & $\begin{array}{l}(19.3) \\
(78.9) \\
(1.8) \\
(100)\end{array}$ & $\begin{array}{l}(16.7-22.1) \\
(75.9-81.6) \\
(0.9-2.9)\end{array}$ \\
\hline $\begin{array}{l}\text { Frequency of church attendance } \\
\text { Once a week or more } \\
\text { Occasionally }(\leq 1 / \text { mouth }) \\
\text { Never } \\
\text { Total }\end{array}$ & $\begin{array}{r}52 \\
511 \\
121 \\
684\end{array}$ & $\begin{array}{l}(7.6) \\
(74.7) \\
(17.7) \\
(100)\end{array}$ & $\begin{array}{l}(5.7-9.8) \\
(71.3-77.9) \\
(14.9-20.8)\end{array}$ \\
\hline $\begin{array}{l}\text { "Faith is the most importan } \\
\text { influence in my life" } \\
\text { Agree } \\
\text { Disagree } \\
\text { Don't know } \\
\text { Total }\end{array}$ & $\begin{array}{r}151 \\
492 \\
41 \\
684\end{array}$ & $\begin{array}{l}(22.1) \\
(71.9) \\
(6.1) \\
(100)\end{array}$ & $\begin{array}{l}(19.0-25.4) \\
(68.4-75.3) \\
(4.3-8.0)\end{array}$ \\
\hline
\end{tabular}




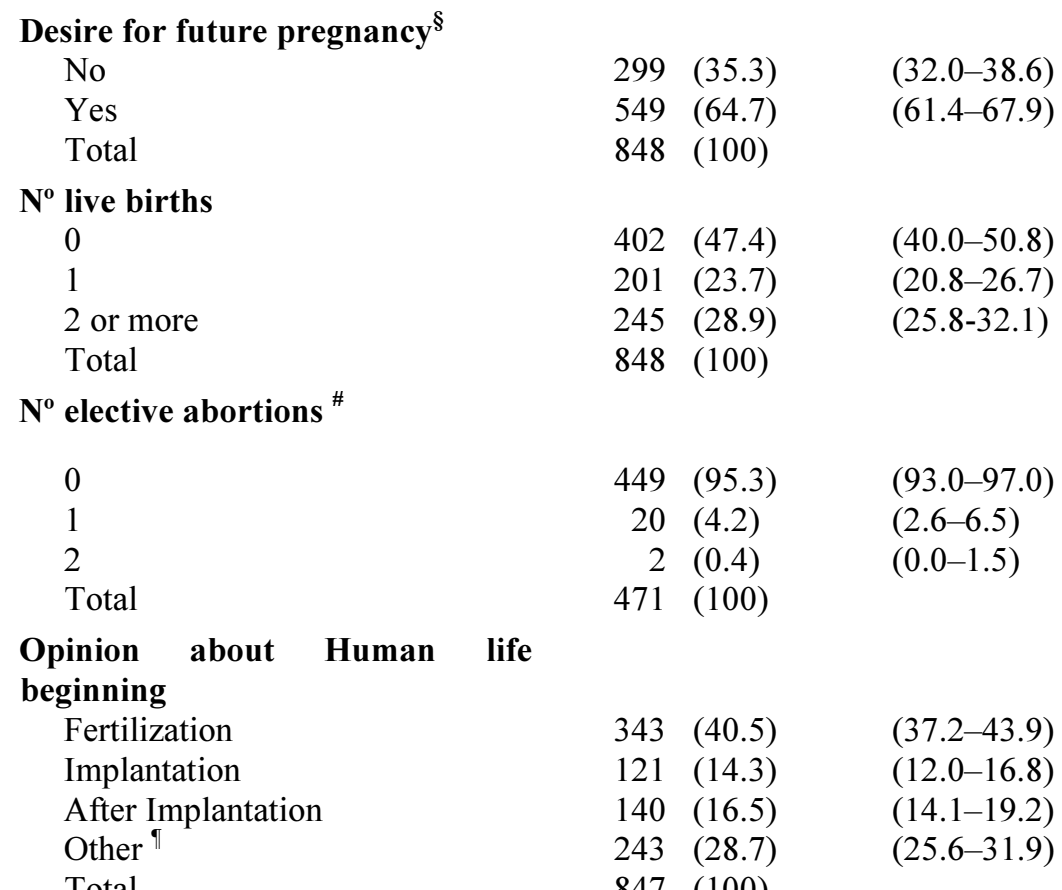

95\% CI: $95 \%$ confidence interval of the proportion.

* Technical college: a college offering students courses in technical and other subjects after they have left school.

${ }^{\dagger}$ Other religions: Protestant $(n=2)$. Orthodox $(n=4)$. Buddhist $(n=2)$. Hindu $(n=1)$. Muslim ( $n=5)$. Jewish $(n=1)$.

*Variables apply only to women who have a religious affiliation.

${ }^{\S}$ No: refers to women who clearly state that they do not want to get pregnant the future. Yes: refers to women who want to get pregnant in the future and those who are not sure about a future pregnancy.

${ }^{\#}$ Variable refers only to women that have been pregnant in the past.

"Other: includes the other options in the questionnaire: "there is no exact time", "I am not sure", "I do not have an opinion" and "sometime before fertilization". 
Table 2. Percentages of Spanish women that had ever used or were using any birth control method

\begin{tabular}{lcc}
\hline BIRTH CONTROL METHOD & $\begin{array}{c}\text { Ever used } \\
\text { (\% of women *) }\end{array}$ & $\begin{array}{c}\text { Currently used } \\
\text { (\% of women *) }\end{array}$ \\
\hline Male Condom & 66.4 & 38.3 \\
Oral contraceptives & 59.2 & 29.9 \\
Intrauterine device (IUD) & 14.7 & 6.3 \\
Vasectomy & 4.6 & 4.5 \\
Withdrawal & 9.7 & 2.8 \\
Contraceptive Patch & 3.3 & 1.5 \\
Vaginal Ring & 2.6 & 1.9 \\
Diaphragm, Cap & 4.0 & 1.7 \\
Natural Methods ${ }^{\dagger}$ & 1.7 & 0.3 \\
Hormonal Implant/Injection & 2.5 & 1.7 \\
Calendar-Rythm Method & 2.6 & 0.6 \\
Abstinence for long periods & 1.7 & 1.2 \\
Postcoital Pill & 3.9 & 0.4 \\
\hline * Percentages do up to 100 because women could be using more than one method. \\
${ }^{\dagger}$ Natural Methods: includes Billings, Sympothermal and Lactational-Amenorrea \\
Methods
\end{tabular}


Table 3. Women's opinions and attitudes related to postfertilization effects of family planning methods.

\begin{tabular}{|c|c|c|}
\hline OPINION OR ATTITUDE & n $(\%)$ & $95 \% \mathrm{CI}$ \\
\hline \multicolumn{3}{|c|}{$\begin{array}{l}\text { Would consider using a method that } \\
\text { may work after fertilization? }\end{array}$} \\
\hline $\begin{array}{l}\text { Yes } \\
\text { No } \\
\text { Unsure } \\
\text { Total }\end{array}$ & $\begin{array}{l}282(33.3) \\
380(44.8) \\
186(21.9) \\
848(100)\end{array}$ & $\begin{array}{l}(30.1-36.5) \\
(41.4-48.2) \\
(19.2-24.8)\end{array}$ \\
\hline $\begin{array}{l}\text { Would consider using a metl } \\
\text { may work after implantation? } \\
\text { Yes } \\
\text { No } \\
\text { Unsure } \\
\text { Total }\end{array}$ & $\begin{array}{l}170(20) \\
481(56.7) \\
197(23.2) \\
848(100)\end{array}$ & $\begin{array}{l}(17.4-22.9) \\
(53.3-60.1) \\
(20.4-26.2)\end{array}$ \\
\hline $\begin{array}{l}\text { Decision about using a meth } \\
\text { learning it may work after fert } \\
\text { Stop using } \\
\text { Continue using } \\
\text { Unsure } \\
\text { Total }\end{array}$ & $\begin{array}{l}407(48) \\
208(24.5) \\
233(27.5) \\
848(100)\end{array}$ & $\begin{array}{l}(44.6-51.4) \\
(21.7-27.6) \\
(24.5-30.6)\end{array}$ \\
\hline \multicolumn{3}{|c|}{$\begin{array}{l}\text { Decision about using a method after } \\
\text { learning it may work after } \\
\text { implantation }\end{array}$} \\
\hline $\begin{array}{l}\text { Stop using } \\
\text { Continue using } \\
\text { Unsure } \\
\text { Total }\end{array}$ & $\begin{array}{l}531(62.6) \\
105(12.4) \\
212(25) \\
848(100)\end{array}$ & $\begin{array}{l}(59.3-65.9) \\
(10.2-14.8) \\
(22.1-28.1)\end{array}$ \\
\hline $\begin{array}{l}\text { Embryonic loss' cause }{ }^{\dagger} \\
\text { Not important } \\
\text { Important } \\
\text { Unsure } \\
\text { Total }\end{array}$ & $\begin{array}{l}533(62.9) \\
170(20) \\
145(17.1) \\
848(100)\end{array}$ & $\begin{array}{l}(59.5-66.1) \\
(17.4-22.9) \\
(14.6-19.8)\end{array}$ \\
\hline \multicolumn{3}{|c|}{$\begin{array}{l}95 \% \text { CI: } 95 \% \text { confidence interval of the proportion. } \\
\text { * Other: includes the other options in the questionnaire: "there is no exact } \\
\text { time", "I am not sure", "I do not have an opinion" and "sometime before } \\
\text { fertilization". } \\
\text { † Embryonic loss' cause: refers to whether it is important to distinguish } \\
\text { spontaneous embryo losses from those that may be caused by birth control } \\
\text { methods. }\end{array}$} \\
\hline
\end{tabular}


Table 4. Variables significantly associated with women's potential decisions about postfertilization effects of family planning methods

\begin{tabular}{|c|c|c|c|c|c|c|c|}
\hline \multirow{3}{*}{\multicolumn{2}{|c|}{$\begin{array}{l}\text { VARIABLES ASSOCIATED } \\
\text { WITH WOMEN'S DECISIONS }\end{array}$}} & \multicolumn{6}{|c|}{ WOMEN'S DECISIONS ODDS RATIO * $(95 \%$ CI $)$} \\
\hline & & \multicolumn{2}{|c|}{$\begin{array}{l}\text { Would use a method that occasionally works } \\
\text { after }\end{array}$} & \multicolumn{4}{|c|}{$\begin{array}{l}\text { Would continue using a method after } \\
\text { learning it works after }\end{array}$} \\
\hline & & & implantation & \multicolumn{2}{|c|}{ fertilization } & \multicolumn{2}{|c|}{ implantation } \\
\hline $\begin{array}{l}\text { Human life } \\
\text { beginning }\end{array}$ & $\begin{array}{l}\text { Fertilization } \\
\text { Implantation } \\
\text { After Implantation } \\
\text { Other }^{\dagger}\end{array}$ & $\begin{array}{ll}1 & \text { (ref.) } \\
1.9 & (1.2-3.1) \\
2.2 & (1.4-3.4) \\
1.6 & (1.1-2.3)\end{array}$ & $\begin{array}{ll}1 & \text { (ref.) } \\
1.3 & (0.7-2.3) \\
1.9 & (1.2-3.1) \\
1.7 & (1.1-2.6)\end{array}$ & $\begin{array}{l}1 \\
1.4 \\
3.7 \\
2.1\end{array}$ & $\begin{array}{l}\text { (ref.) } \\
(0.8-2.4) \\
(2.3-5.8) \\
(1.4-3.2)\end{array}$ & $\begin{array}{l}1 \\
1.9 \\
4.6 \\
3.5\end{array}$ & $\begin{array}{l}\text { (ref.) } \\
(0.9-4.3) \\
(2.5-8.8) \\
(1.9-6.3)\end{array}$ \\
\hline $\begin{array}{l}\text { Embryonic loss } \\
\text { cause }\end{array}$ & $\begin{array}{l}\text { Not important } \\
\text { Important }\end{array}$ & $\begin{array}{ll}1 & \text { (ref.) } \\
0.5 & (0.4-0.8)\end{array}$ & n.s. & $\begin{array}{l}1 \\
0.5\end{array}$ & $\begin{array}{l}\text { (ref.) } \\
(0.4-0.7)\end{array}$ & $\begin{array}{l}1 \\
0.3\end{array}$ & $\begin{array}{l}\text { (ref.) } \\
(0.2-0.6)\end{array}$ \\
\hline Religion & $\begin{array}{l}\text { No } \\
\mathrm{Yes}^{\S}\end{array}$ & $\begin{array}{ll}1 & \text { (ref.) } \\
0.6 & (0.4-0.9)\end{array}$ & n.s. & $\begin{array}{l}1 \\
0.6\end{array}$ & $\begin{array}{l}\text { (ref.) } \\
(0.4-0.9)\end{array}$ & n.s. & \\
\hline Marital status & $\begin{array}{l}\text { Not married } \\
\text { Married }\end{array}$ & $\begin{array}{ll}1 & \text { (ref.) } \\
0.6 & (0.4-0.8)\end{array}$ & n.s. & n.s. & & n.s & \\
\hline $\begin{array}{l}\text { Country of } \\
\text { origin }\end{array}$ & $\begin{array}{l}\text { Spain } \\
\text { Central/South-America } \\
\text { Others }\end{array}$ & n.s. & $\begin{array}{ll}1 & \text { (ref.) } \\
2.4 & (1.3-4.5) \\
1.1 & (0.4-3.1)\end{array}$ & n.s. & & n.s. & \\
\hline Annual income & $\begin{array}{l}<20000 € / \text { year } \\
20-40000 € / \text { year } \\
>40000 € / \text { year } \\
\text { Do not know/answer }\end{array}$ & n.s. & $\begin{array}{ll}1 & \text { (ref.) } \\
1.9 & (1.2-3.2) \\
4.4 & (1.3-15) \\
1.9 & (1.2-2.9)\end{array}$ & n.s. & & n.s. & \\
\hline
\end{tabular}

* All logistic regression models are adjusted for the variables shown in the table and education, desire for future pregnancy, number of pregnancies and number of elective abortions. Only statistically significant variables are displayed.

n.s.: statistically not significant

"Other: includes the other options in the questionnaire: "there is no exact time", "I am not sure", "I do not have an opinion", "sometime before fertilization."

"Embryonic loss' cause: refers to whether it is important to distinguish natural embryo losses from those that may be caused by birth control methods.

$\S$ Yes: refers to women who have any religious affiliation. 